\title{
White phosphorus genotoxicity
}

\author{
Anton Mindubaev ${ }^{1 *}$, Edward Babynin ${ }^{3}$, Salima Minzanova ${ }^{2}$, Elena Badeeva ${ }^{2}$, Yaw Akosah ${ }^{3}$ \\ ${ }^{1}$ Institute of Power Engineering and Advanced Technologies, FRC Kazan Scientific Center, Russian Academy of Sciences \\ ${ }^{2}$ A.E. Arbuzov Institute of Organic and Physical Chemistry of Kazan Scientific Center of Russian Academy of Sciences \\ ${ }^{3}$ Kazan (Volga region) federal university, Kazan
}

\begin{abstract}
The genotoxicity of white phosphorus was previously evaluated using the Ames test, which demonstrated the absence of toxicity. However, with all the advantages of this method, the use of the Ames test has some shortfallsin assessing genotoxicity. For this purpose, a series of supplementary tests wereconducted, including the SOS-lux test for DNA damaging activity. In the present work, the SOS-lux test confirmed the genotoxicity of white phosphorus. Based on a review of the literature, our results denote a first report on the genotoxic properties of white phosphorus. Allium test showed the mitotoxic effect of white phosphorus on eukaryotic cells.
\end{abstract}

\section{Introduction}

Our earlier publications $[1-4]$ were devoted to the microbiological conversion of white phosphorus to biogenic phosphate. The work performed by our team is the first example of the assimilation of the artificial xenobiotic white phosphorus by the biosphere. Nevertheless, biodegradation sometimes leads to the formation of more toxic substances, A.KA. "lethal metabolites". Some of them exhibit genotoxicity, leading to an increase in the number of mutations and the emergence of neoplastic disorders. Therefore, the study of biodegradation of xenobiotics should be accompanied by testing for genotoxicity.

\section{Materials and methods}

The SOS-lux test was performed as described in [5]. To assess the cytogenetic effect of phosphorus on eukaryotic cells, the Allium cepa test system was used [6].

The Toxicological Profile of White Phosphorus for 1997 [7] reports the absence of genotoxicity of this substance. In our case, when the Salmonella typhimurium TA1538 strain was incubated in a medium with white phosphorus for 1 hour, the number of mutants did not increase but fell from $10.09 \pm 0.81$ to $9.0 \pm 0.72$. In the positive control with the 2,4 dinitrophenylhydrazine mutagen, their number increased to $22.5 \pm 3.1$. Thus, the genotoxicity of a culture medium with white phosphorus and its metabolites were not observed during this test results.

In assessing the mutagenic and antimutagenic properties of white phosphorus using the SOS-lux test, strong mutagens, the antitumor antibiotic mitomycin $\mathrm{C}$, and hydrogen peroxide were used as controls.

\section{Results}

In comparison to peroxide, white phosphorus turned out to be a weak DNA damaging agent (Fig. 1). However, the concentration of $\mathrm{H}_{2} \mathrm{O}_{2}$ in the experiment was $0.03 \%$, while that of white phosphorus, was $62.5 \mu \mathrm{g} / \mathrm{ml}$, corresponding to $0.00625 \%$. Thus, the $\mathrm{P}_{4}$ concentration was 4.8 times lower than that of peroxide. Since higher concentrations of white phosphorus have a detrimental effect on Salmonella, it was difficult to reliably assess the genotoxicity of P4 in this bacterium. Although it can be assumed that with an increase in DNA concentration, the damaging activity of $\mathrm{P}_{4}$ should only increase. Hence, the low genotoxicity of white phosphorus cannot be generalized due to its comparatively high toxicity to

\footnotetext{
* Corresponding author: mindubaev-az@yandex.ru
} 
cells. A weaker but significant DNA damaging activity of white phosphorus was registered even after diluting the medium, containing $0.2 \% \mathrm{P}_{4}$ to $0.01 \%$.

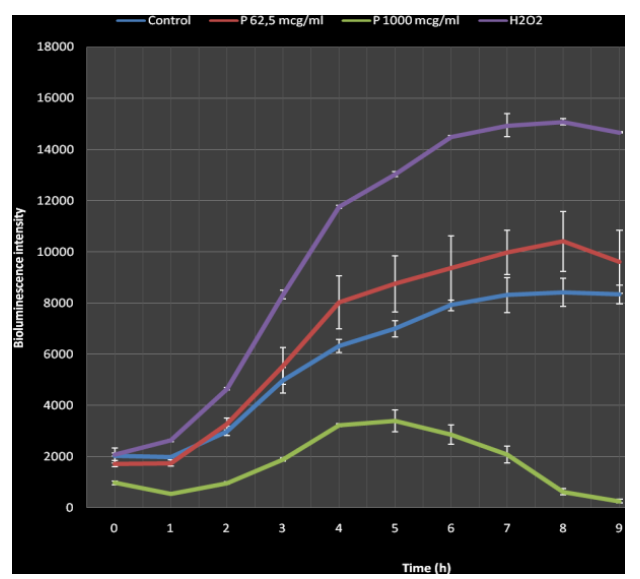

Fig. 1. The effect of white phosphorus on SOS induction with hydrogen peroxide relative to the negative control (medium without mutagen). $\mathrm{P}_{4}$ at a concentration of $62.5 \mu \mathrm{g} / \mathrm{ml}$ is a weak mutagen compared to peroxide. $\mathrm{P}_{4}$ at a concentration of $1000 \mu \mathrm{g} / \mathrm{ml}$ is lethal to microbes after 9 hours of incubation. In the control, SOS induction also slightly increases, which is associated with the growth of the culture and the accumulation of DNA (accordingly, the number of its damages also increases, even in the absence of the mutagen).

It was shown that the presence of white phosphorus leads to lagged growth of onion roots (Fig. 2). It was also found that the mitotic activity of tissues in contact with $\mathrm{P}_{4}$ significantly reduces in comparison to the control, which indicates amitotoxic activity of $\mathrm{P}_{4}$. Analysis of the ratios of mitotic phases showed an augmented proportion of cells at the prophase stage with a corresponding decline in the percentage of other stages (Table 1). This may be due to a blockage of cell division at the end of the prophase stage.

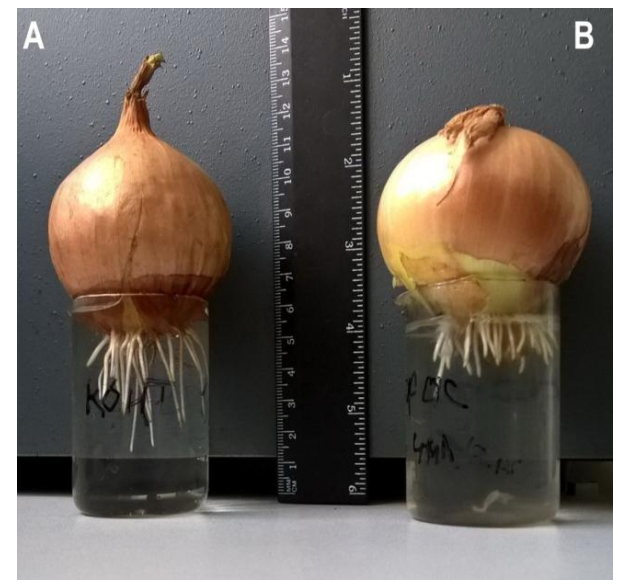

Fig. 2. A clear demonstration of the phytotoxicity of white phosphorus: in its presence (B), the roots significantly lag in growth relative to the control (A). The concentration of $\mathrm{P}_{4}$ in the tested sample was $0.016 \%$. The picture was taken 48 hours after the start of germination.

Table 1. Mitotic index at various concentrations of white phosphorus 


\begin{tabular}{|c|c|c|c|c|}
\hline & Control & $0.008 \%$ & $0.012 \%$ & $0.016 \%$ \\
\hline Mitotic Index (MI) & $7.25 \pm 1.15$ & $3.31 \pm 0.88$ & $2.35 \pm 0.65$ & $1.35 \pm 0.25$ \\
\hline $\begin{array}{c}\text { Metaphase to Prophase ratio } \\
(\mathrm{M} / \mathrm{P})\end{array}$ & 0.77 & 0.72 & 0.64 & 0.42 \\
\hline
\end{tabular}

\section{Conclusions}

The discovery of genotoxic properties in white phosphorus is not surprising, given the high chemical activity of this substance. However, in earlier studies, $\mathrm{P}_{4}$ genotoxicity was not found. Perhaps this was due to insufficient depth of research, after all until now, the genotoxicity of white phosphorus was only determined by the Ames test, which always showed a negative result. This is probably the first time the SOS-lux and the Allium testshave been applied for this purpose, to assess DNA damage and chromosome misalignment. With these methods, the genotoxicity of white phosphorus was demonstrated.

\section{References}

1. A.Z. Mindubaev, A.D. Voloshina, E.V. Babynin, E.K. Badeeva, Kh.R. Khayarov, S.T. Minzanova, D.G. Yakhvarov, Ecology and Industry of Russia, 22(1), 33-37 (2018)

2. A.Z. Mindubaev, E.V. Babynin, A.D. Voloshina, K.A. Saparmyradov, Y.A. Akosah, E.K. Badeeva, S.T. Minzanova, L.G. Mironova, News of NAS RK. Series of geology and technical sciences, 5 (437), 122-128 (2019)

3. A.Z. Mindubaev, S.V. Kuznetsova, V.G. Evtyugin, A.G. Daminova, T.V. Grigoryeva, Y.D. Romanova, V.A. Romanova, V.M. Babaev, D.N. Buzyurova, E.V. Babynin, E.K. Badeeva, S.T. Minzanova, L.G. Mironova., Applied Biochemistry and Microbiology, 56 (2), 194-201 (2020)

4. A.Z. Mindubaev, S.V. Fedosimova, T.V. Grigoryeva, V.A. Romanova, V.M. Babaev, D.N. Buzyurova, E.V. Babynin, E.K. Badeeva, S.T. Minzanova, L.G. Mironova, Y.A. Akosah, J.V. Karaeva, Applied Chemistry and Biotechnology, 11 (1), 69-79 (2021)

5. D.L. Cooper, S.T. Lovett, DNA Repair (Amst), 10 (3), 260-270 (2011)

6. W. Wang, J. W. Gorsuch, J. S. Hughes. Plants for Environmental Studies (6005 J.S. (Eds), New York, NY: CRC Lewis Publishers, 1997)

7. P. Duerksen-Hughes, P. Richter, L. Ingerman, W. Ruoff, S. Thampi, S. Donkin. Toxicological profile for white phosphorus (U.S. Department of health and human services, 1997). 